\title{
GROUNDING PROCEDURAL RIGHTS
}

\author{
N. P. Adams
}

\section{INTRODUCTION}

If Mary culpably commits a crime and then is punished without having been found guilty of that crime through the process of a trial, is Mary wronged? Intuitively, yes. That is, Mary has a right not to be punished absent a trial, even for things that she has done and deserves to be punished for. ${ }^{1}$ The most commonsensical and direct way to explain this wrong is to appeal to Mary's pre-institutional moral right: Mary simply has such a right in virtue of what morality requires in the treatment, particularly in the punishment, of others. Such a right would be one of a class of "general, moral, judicial, procedural rights." 2 This class of rights is often taken to make up an important part of

rule of law and to explain why our punitive institutions must take a particular shape: why we must have trials, juries, judges, appeals, competent legal representation, a right to present evidence, and so on. Absent such

1. Throughout the paper I assume a broadly Anglophone legal setting and appeal to intuitions developed in such a setting. But the rights at stake should generalize to legal settings where trials look very different. This discussion would benefit greatly from a comparative perspective, which unfortunately I do not have the space to provide here. Thanks to an anonymous referee for highlighting this important point.

2. Christopher Heath Wellman, Procedural Rights, 20 LEGAL THEORY 286, 287 (2014). 
procedures, our punitive institutions are unjustified because they violate our (in short) procedural rights.

In a recent article, Christopher Heath Wellman argues for the surprising claim that there are no procedural rights. ${ }^{3}$ His characteristically clear and challenging argument goes against the orthodox and seemingly uncontested consensus that such procedural rights exist and are fundamental constraints on our legal systems. Wellman effectively undermines potential grounds for procedural rights that other theorists have offered, so concludes that, in lieu of other possible grounds, we have no procedural rights.

Here I offer two novel grounds for such rights and so conclude that we do have some procedural rights. As with other theorists who have addressed this problem, including Robert Nozick, R. A. Duff, and Larry Alexander, I focus on the ideas that procedures protect us against unreasonable risks and that using procedures can instantiate a certain kind of respectful treatment. ${ }^{4}$ Although I reject his general skeptical conclusion, Wellman forces us to

3. Ibid.

4. Robert Nozick, Anarchy, State, and Utopia (1974); R.A. Duff, Trials and Punishments (1991); Larry Alexander, Are Procedural Rights Derivative Substantive Rights? 17 LAW \& PHIL. 19 (1998). For a different perspective grounding some procedural constraints in the rule of law, see Hock Lai Ho, The Criminal Trial, the Rule of Law and the Exclusion of Unlawfully Obtained Evidence, 10 CRIM. LAW \& PHIL. 106 (2016). 
reconsider both which procedural rights we have and in what way people are wronged when such rights are violated.

In Section II I sketch Wellman's position and extrapolate some desiderata for an adequate theory of procedural rights. The details of his arguments are considered more fully throughout the article as I address his concerns. Section III focuses on the idea that our right against unreasonable risks grounds a right to an institutionalized system of punishment that must include certain procedures. Section IV applies Philip Pettit's notion of robust goods to punishment and argues that we have a right to security that obligates others to follow certain procedures in some circumstances. ${ }^{5}$ I conclude that there are two distinct grounds—risk protection and securityfrom which we can derive procedural rights of two related but interestingly distinct kinds.

\section{THE SKEPTICAL CHALLENGE}

Wellman's view is nuanced and can easily be mistaken for more implausible nearby views. To be clear about his position, it is first important to make two distinctions: first, between moral and legal rights and second, between preinstitutional and post-institutional moral rights. Wellman does not deny, for example, that United States citizens have a positive legal right against double jeopardy and he does not deny that such a legal right may very well have

5. Philip Pettit, The Robust Demands of the Good (2015). 
moral grounds, such as concerns of reliability. Nor does he deny that once an institution exists and has committed itself not to prosecute citizens twice for the same crime, this commitment can generate a moral right against double jeopardy. What Wellman denies is the existence of pre-institutional moral procedural rights.

Wellman begins by arguing that we do not have a pre-institutional moral right against double jeopardy. It is clear that a right against double jeopardy provides us with some protections, particularly by preventing a sort of harassment that could unreasonably interfere with citizens' lives and that might lead to more innocents being convicted or pleading guilty simply to avoid the costs of repeated prosecution. But if we can imagine an institutional arrangement that does a better job securing these benefits without a restriction on double jeopardy, is anything lost if we choose to change our institution and set aside the restriction? There does not seem to be anything about repeatedly trying a case that is intrinsically objectionable; after all, double jeopardy is only triggered under certain conditions and with respect to certain jurisdictions. Wellman gives the instructive example of an institution that did not protect against double jeopardy but significantly raised the evidentiary standard that must be met for conviction. It could be the case that such an institution would convict more guilty people and convict fewer innocent people than an institution with protections against double jeopardy but a lower evidentiary standard. 
If we lack a pre-institutional moral right against double jeopardy, then the choice between these institutional arrangements is live and interesting: it would make sense to investigate the choice empirically in order to determine which arrangement is better. If we have a pre-institutional moral right against double jeopardy, though, then only the institutional arrangement that protects against double jeopardy could possibly be justified. Of course even if we lack a right against double jeopardy, it may still be the case that we should opt for a system with double jeopardy protections because the alternatives simply enable too much harassment. But at this point we are weighing the costs and benefits of various institutional alternatives, which is precisely the sort of weighing that is irrelevant if we have a pre-institutional moral right against double jeopardy that serves as a side constraint on our institutions. It is hard to see why this choice would not be open to us based on a very specific pre-institutional moral right against double jeopardy.

Wellman's argument against a pre-institutional moral right to a fair trial, or more generally each individual's "right against being punished until she has been proven guilty by a fair, reliable, and public process," proceeds differently. ${ }^{6}$ Wellman imagines a case where a robbery is committed in the utopian Justland but the perpetrator cannot be discovered. In order to mitigate the effects of this uniquely unpunished crime, the society decides by plebiscite to punish someone chosen by lottery. Sandra is chosen by the lottery and is subsequently punished but, in the challenging twist, Sandra

6. Wellman, supra note 1, at 290. 
actually committed the crime. Wellman contends that none of Sandra's rights have been violated-Sandra is not wronged by this punishment-because by committing the crime she forfeited her right against being punished. ${ }^{7}$ There is no question of Sandra's legal or post-institutional rights being violated because ex hypothesi the Justlanders' institutions authorized the lottery. If none of Sandra's rights have been violated despite the fact that she was punished by such an arbitrary procedure, then she must not have a preinstitutional moral right against being punished absent a trial.

To be clear, the Justlanders may be blameworthy for using the lottery to punish Sandra. But wrongness is a question of fact-relative or objective permissibility whereas blameworthiness is a question of evidence-relative or subjective permissibility. ${ }^{8}$ Whether Sandra was wronged is a question about the rights she actually has while whether the Justlanders were blameworthy is a question about their mental state when they acted. So Wellman is willing

7. On Wellman's rights forfeiture view of punishment, see Christopher Heath Wellman, The Rights Forfeiture Theory of Punishment, 122 Eтнics 371 (2012). Much of the discussion below presumes at least a weak rights forfeiture view, which I endorse, but does not presume the strong rights forfeiture view, which I do not.

8. On the distinction between fact-relative, evidence-relative, and belief-relative permissibility, see Derek PARFit, ON What MAtTERS 150 (vol. 1, 2012). On wrongness as a fact-relative matter, see Peter A. Graham, In Defense of Objectivism about Moral Obligation, 121 Eтнісs 88 (2010). Of course, not everyone conceives of wrongness and blameworthiness in this way but Wellman and I both do; see Wellman, supra note 1 , at 297. 
to admit that we should blame the Justlanders for employing an arbitrary procedure that, as luck would have it and unbeknownst to them, happened to punish the culpable offender. The distinct question for procedural rights is whether Sandra was wronged by the Justlanders' actions.

Wellman's case for his broad skeptical conclusion that there are no procedural rights rests primarily on his discussion of these two cases. In support he also considers and rejects a variety of grounds that other theorists have proposed for procedural rights and he considers what implications his skepticism might have for the human right to due process. Finding no firm basis for these two particular procedural rights in the literature, Wellman generalizes his conclusion and claims that we have no such rights at all.

In order to address this skepticism below, it helps to clarify the point of a theory of procedural rights, which will inform what sorts of rights will be plausible components of such a theory. As noted, certain kinds of rights will not do: positive legal procedural rights and post-institutional moral rights that arise out of a commitment by the institution to follow certain procedures. But why are these sorts of rights insufficient? What do preinstitutional moral procedural rights do that these rights cannot?

Notice, first, what legal and post-institutional moral rights can do: they can explain our judgment that subjects of a liberal constitutional legal regime are wronged if they are punished absent a trial, or more generally without first going through a fair set of procedures. Since such institutions 
commit themselves to using trials and other familiar procedures, subjects of such institutions have legal and post-institutional moral rights that are violated if they are punished without the appropriate procedures being used.

This is important for the skeptic because it provides the basis for a plausible error theory about pre-institutional moral procedural rights. I personally have the intuition that people are wronged if they are punished without first going through fair procedures even outside the context of a liberal constitutional legal regime. However, this may be because my intuitions were formed in a context where people are so wronged but the explanation of the wrongness that fuels my intuitions is grounded in the legal and post-institutional moral rights that I am familiar with, not preinstitutional moral rights. If we can explain away our considered judgments about such cases, then denying the existence of pre-institutional moral procedural rights is not as implausible as it may seem at first glance.

That said, we often employ our judgments about punishment and procedural rights outside a liberal constitutional context and this is where the skepticism matters. First, when considering areas of the world that lack rule of law, we are tempted to say that people who are punished without the relevant procedures-without trials, without juries, without presentation of evidence, without an independent judiciary, and so on-are wronged. In these cases they cannot be wronged in virtue of legal or post-institutional moral rights precisely because there are no such rights in the absence of institutions making specific commitments. If (even culpable) people are 
genuinely wronged when punished in such circumstances, it must be because they have pre-institutional moral rights that are being violated.

Second, and relatedly but not identically, pre-institutional moral rights constrain our choices between institutional alternatives, as illustrated with the example of double jeopardy. ${ }^{9}$ If there is a pre-institutional moral procedural right to double jeopardy, then any institution that does not protect subjects against double jeopardy is necessarily wronging its subjects, i.e. violating their rights. But if such a procedural right does not exist, then the reasons that count in favor of a right against double jeopardy can be balanced against other considerations.

Legal or post-institutional moral rights cannot constrain our choices among institutional alternatives precisely because such rights are absent without the institutions that we are choosing among. ${ }^{10}$ Skepticism about procedural rights importantly entails that whatever reasons institutions have to establish specific procedures, securing citizens' pre-institutional moral

9. Wellman, supra note 1 , at 288-89.

10. To be clear, this does not mean that what legal or post-institutional moral rights people might have under a particular regime cannot serve as a point of comparison between institutional alternatives. The point is that we cannot take the existence of such rights to constrain our choices between alternatives: the fact that you would have a right to $\mathrm{P}$ under regime A tells us nothing about whether choosing regime $\mathrm{B}$, where you are not provided $\mathrm{P}$, violates your rights and so tells us nothing about whether choosing regime B is unjustified. That having a right to $\mathrm{P}$ under $\mathrm{A}$ is a good-making feature of $\mathrm{A}$ is independent of whether opting for B violates your rights. 
procedural rights is not among them. This is in distinct contrast to many other cases: paramount among the reasons for there to be a law against murder is people's pre-institutional moral right to life. Any legal regime that does not include a law against murder is unjustified because it fails to protect that right. Denying the existence of pre-institutional moral procedural rights thus changes the sort of justification that must be given for our choices among institutional alternatives. In sum, procedural rights of the relevant sort play two important roles: constraining choices among institutional alternatives and explaining the particular wrong of punishing someone absent sufficient procedures.

Before proceeding, two notes: first, nothing I say here contradicts Wellman's conclusion that there is no pre-institutional moral right against double jeopardy. In fact, Wellman convinced me that there is not. I take objection to his argument against the (to my mind much more fundamental) right to a fair trial and to his more general skeptical conclusion. An important lesson of his article, however, is that at least some of what we conceive of as pre-institutional moral procedural rights should instead be understood purely instrumentally. Wellman's argument importantly clears the way for a greater variety of institutional alternatives and so hopefully helps us think better about how to understand and improve our legal institutions.

Second, it is worth noting that Sandra has a pre-institutional moral right that the punitive lottery seems to violate: the right to be treated in the same way as others under the same legal regime. In Justland, all other 
punishments have resulted from trials, but in this one case Sandra is subject to a lottery and this seems to wrong her because it is unfair. The sense of fairness being appealed to here is of a different, more relational sort than the fairness appealed to in the right to a fair trial. While it is plausible that we have a right to relationally fair treatment, however, the complaint of relational unfairness cannot ground procedural rights of the relevant sort. The primary problem is that seriously unjust legal regimes can treat everyone fairly in the relational sense by treating them all equally unjustly. Even worse, someone who metes out punishment to people without following any procedures at all can avoid the complaint of relational unfairness as long as they avoid procedures equally across cases. So relational unfairness of this kind cannot ground procedural rights that do the work we want them to do, even though a pre-institutional moral right against relationally unfair treatment can explain some nearby wrongs (and so could also contribute to the skeptic's error theory).

\section{SYSTEMIC PROCEDURAL RIGHTS}

Most discussions of procedural rights correctly focus on the idea of risk. People not only have pre-institutional moral rights against being harmed, they have rights against unreasonable risks of harms. ${ }^{11}$ Such rights explain,

11. Claire Finkelstein, Is Risk a Harm? 151 U. PEnN. LAW Rev. 963 (2003); John Oberdiek, Towards a Right Against Risking, 28 LAW \& PHIL. 367 (2009). 
for example, why I wrong you if I take five bullets out of my revolver and fire it at you for my amusement but happen to hit an empty cylinder. Even though I did not physically harm you, as I would have had I fired the single remaining bullet, I still wronged you because I unreasonably risked your life. As this example makes obvious, what amounts to reasonable risk depends on a variety of factors: the gravity of harm, the likelihood of harm, the purpose of the risk, and so on.12 Imposing a small risk of death may be unreasonable while imposing a large risk of a light scratch may be reasonable; imposing a tiny risk of a burn to save many lives is reasonable while imposing a tiny risk of a burn for my amusement may not be. Since punishment involves the intentional infliction of harm, our general right against unreasonable risk also protects us against unreasonable risks of punishment. ${ }^{13}$

A pre-institutional moral right against an unreasonable risk of punishment can ground procedural rights of a certain sort. Wellman admits this when he considers a modified Justland case where, instead of simply

12. A terminological note: I use 'harm' in a non-moralized sense to mean the setback of interests. Some philosophers prefer to use 'harm' such that only wrongful setbacks are harmful. This seems to me quite mistaken, although I admit that there may be a constraint such that very minor setbacks are not properly thought of as harm. Thanks to an anonymous referee for pushing me to clarify this.

13. The relevant risk is risk of wrongful punishment: if I have culpably committed an offense and so forfeited my right against punishment, that punishment is not wrongful and so any risk of that punishment is not unreasonable, as Wellman emphasizes in the Sandra example. 
using a lottery in one aberrant instance, the punitive lottery is routinely used to mete out punishment. ${ }^{14}$ It is clear that a lottery system exposes all Justlanders to unreasonable risks of punishment precisely because the lottery is arbitrary and does not track who is liable to punishment. Because lotteries are arbitrary, we have a pre-institutional moral right against a system that uses routine punitive lotteries. Like the ostensible procedural right against double jeopardy, this is a negative procedural right: it tells us what kinds of procedures are insufficiently protective of our rights against unreasonable risks.

Similarly, we have a pre-institutional moral right to an institutionalized system of punishment in general. This is part of the familiar Lockean justification for the state, which Wellman has endorsed. ${ }^{15}$ In the state of nature, private individuals will take it upon themselves to punish. However, due to personal bias, disagreements, and other factors, this would lead to a great deal of wrongful punishment. Being in the state of nature, where ex hypothesi there are no political institutions, puts us at unreasonable risk of punishment and so violates our rights. This very general right to an institutionalized system of punishment is not yet a procedural right of the relevant sort but thinking about unreasonable risk of punishment in this manner can also ground rights to more specific procedures.

14. Wellman, supra note 1, at 292.

15. Christopher Heath Wellman, Samaritanism and the Duty to Obey the Law, in CHRISTOPHER Heath Wellman \& A. John Simmons, Is There a Duty to Obey the LaW? 2, 6-10 (2005). 
Consider the procedure of the trial in its most general sense. Can we imagine any system that does not include trials but is sufficiently reliable at meting out deserved punishment? What plausible alternatives are there? Summary punishment of suspects by law enforcement? Following mob mentality? The general notion of a trial encompasses many variations; even a king hearing both sides of a case and simply deciding on his own monarchical judgment is a trial (if an inadequate one). Institutions without trials of any sort seem paradigmatically unreliable precisely because they by definition do not include testing of the claim of guilt via consideration of the details of the case. These examples are somewhat ludicrous and I do not want to be unfair to the skeptic. But it is difficult for me to imagine a judicial institution that does not include trials and is sufficiently reliable such that it does not violate its subjects' right against unreasonable risk of punishment. If this is correct, then we have a pre-institutional moral right to a punitive system that uses trials to determine guilt.

This argument schema can show that we have further particular procedural rights. For example, a trial system that did not include an appeal process of some sort seems unreasonably risky given that any particular trial can fail in a huge variety of unseen ways. Similarly, the right to a speedy trial follows from the fact that lengthy and indefinite detention without a trial is unreasonably risky given that it significantly harms people irrespective of 
determination of their guilt. ${ }^{16}$ The point is that focusing on unreasonable risk in the system shows that there are at least some familiar procedures the absence of which would make the system unreasonably risky. Some procedural rights that we take for granted cannot be grounded in this way, as Wellman's discussion of double jeopardy demonstrates. I cannot here undertake the large task of considering our legal systems' many procedures and ask whether their absence or presence is absolutely necessary to avoid an unreasonable risk of punishment. The point is that we have some procedural rights.

Procedural rights of this systemic sort—rights to an institutionalized system of punishment that includes certain procedures-can clearly play one role we identified for a theory of procedural rights in the previous section. Systemic rights set constraints on our choices between institutional alternatives. When considering whether we are justified in establishing and operating a punitive system without trials or with trials, we have to choose the system with trials. Although the system without trials may be much less costly in terms of time and resources, such a system would impose an unreasonable risk of undeserved punishment on all its subjects and so would

16. As an anonymous referee emphasized, this is not quite the same as "meting out hard treatment," which is how I originally framed the problem. Note, however, that I am not claiming that pre-trial detention in general is problematic but that "lengthy and indefinite" detention is. The details will depend on how the various values that undergird the justification of pre-trial detention are balanced against the harms imposed by such detention. 
violate their pre-institutional moral rights. We cannot undertake the same weighing of costs and benefits as we could when we were considering two systems that do not violate pre-institutional moral rights, like one including double jeopardy and one not. We have to opt for the institutional alternative that incorporates trials.

That said, there is a significant problem with systemic procedural rights: they utterly fail to play the other role that we identified, namely explaining how actually punishing someone using an unfair procedure wrongs them. Systemic rights are not triggered by a particular unfair trial or unjust procedure. Instead, they are in some sense environmental: without a system with the appropriate procedures, we are all subject to a constant risk of unjustified punishment. This means systemic rights are silent in both of the cases where the role of identifying particular wrongs by unfair procedures is most pressing.

First, in the state of nature, we would all be wronged all the time by the lack of political institutions for meting out punishment. But, as Wellman notes, systemic rights are only plausibly held against collectives because no individual can establish and maintain an institutionalized system of punishment on her own. ${ }^{17}$ An individual in the state of nature may have a duty to do her fair share towards establishing such a system, but if she has done her fair share systemic rights cannot make any more demands on her. Thus if we imagine a case where she has done her fair share but there is still

17. Personal correspondence. 
no punitive system because not enough others have contributed, systemic rights are silent. If she proceeds to punish someone on her own under such conditions, then, systemic rights do not provide any basis for saying that she acts wrongfully, regardless of whether she uses fair procedures or not.

Similarly, in the case where Justland uses routine punitive lotteries rather than trials, all Justlanders are being wronged by the unreasonable risk of undeserved punishment that they constantly face due to the features of their system. But in the original Sandra case, Justland is stipulated to have a generally just system of punishment. In normal cases, Justland uses trials and courts and appeals and everything else that we want. What makes Sandra's case difficult is precisely that the punitive lottery is an aberration rather than a regular feature of the system and so Sandra seemingly has no complaint of being exposed to an unreasonable risk of punishment from the system. In both cases systemic procedural rights fail to explain the wrong that procedural rights are often precisely used to explain, namely how individuals are specifically wronged by punishment that results from unfair procedures. The wrong of an unreasonable risk of punishment from unreliable punitive systems and the wrong of punishment that results from particular unfair procedures are simply distinct.

This is a significant problem for grounding procedural rights only in systemic concerns. In the rest of this section I push the case for systemic procedural rights as far as I plausibly can. In part this is because I think the Justland case obscures an important feature of systemic rights and pushing 
the case for such rights illuminates the nature of systemic procedural rights more broadly. Ultimately, however, I am not confident that this problem can be satisfactorily answered by appealing only to systemic procedural rights. If not, and if systemic rights are the only solid ground for procedural rights, then we may simply have to accept that procedural rights cannot do everything we have traditionally taken them to do. But this is also why I offer another ground for procedural rights in the next section. I think these distinct arguments are both correct and that they ground related but distinct kinds of procedural rights.

Systemic rights can explain why Sandra is wronged in Justland because the risk that Sandra is exposed to is not simply the risk of the arbitrary punitive lottery. The Justlanders' system imposes an unreasonable risk on its subjects simply because it can allow a punitive lottery to be enacted. In our own actual legal systems, such a plebiscite would be struck down by the courts even if it successfully passed. Sandra is wronged in the one-off lottery case precisely because the Justlanders' system lacks the sort of contra-majoritarian checks that a fair and reliable judicial system must contain. Fair and reliable systems have judicial review precisely to restrain the majority from making this sort of "wacky" decision. ${ }^{18} \mathrm{~A}$ system that does not have serious restraints on the sorts of clearly arbitrary treatment of individuals that this lottery represents is ipso facto violating its citizens' rights. All the Justlanders are subject to an unfair and unreliable system. The

18. Wellman, supra note 1 , at 290. 
fact that they only used the lottery once is irrelevant; the problem is that they could ever use a punitive lottery at all.

A resolute skeptic about procedural rights might object that the mere capacity of the Justlanders to use a one-off punitive lottery does not subject Sandra to unreasonable risks, for two reasons. The first is that the Justlanders only use the lottery after a rigorous process: "After extensive public discussion and deliberation, all ten million Justlanders voted in the plebiscite, and the motion was affirmed by a two-thirds majority."19 Not only was there a vote, it was a direct vote rather than by representatives, it was taken only after extensive public deliberation, there was unanimous participation, and the plebiscite passed with two-thirds of the vote rather than a mere majority. While the Justlanders' system contains some risk, it is not an unreasonable risk because the stringent conditions on this lottery are very unlikely to be met again. The mere fact that the risky outcome occurred does not show that the risk was unreasonable.

This goes well with the other point the resolute skeptic might make, namely that no system can perfectly protect against such a risk. Given the two-thirds majority, for example, the U.S. Constitution could have been amended to make such a lottery legally permissible, rendering judicial review irrelevant. Yet we do not think that the mere possibility that the Constitution could be amended in such a way means that we are subject to unreasonable risk of punitive lotteries. We need some notion of 19. Ibid. 
unreasonable risk that does not entail that any fallible system, i.e. every actual system, is unreasonably risky.

While it is true that there are no perfect systems, this ignores two salient points. The first is that some legal systems, like Germany's, have rights that explicitly cannot be amended by the population regardless of a vote; perhaps there is good reason to think that lacking such unchangeable elements is unreasonably risky in light of the vagaries of majority rule. Indeed, this seems to be the most obvious justification for the German system, which was implemented after World War II. Of course, even this is not perfect as the constitutional order as a whole could collapse.

This leads to the second point. The fairness and reliability of a trial must be assessed relative to the overall system in which the trial occurs. Consider all the elements of a trial that contribute to its fairness and reliability. First, there are all the norms that are independent of the formal constraints. These norms are a community matter, developed over time and tested in innumerable cases. No matter the formal features of a single trial, it would need to be bolstered by reliable norms because how rules operate in practice is a function of norms. It was not only the Justlanders' institutions that failed, it was also their sense of justice.

Second, the fairness and reliability of all the formal features that contribute to the fairness and reliability of a trial—the judge, presentation of evidence, adequate legal representation, and so on-are themselves dependent on the entire system. The sort of judge that profoundly 
contributes to the fairness and reliability of a trial is bound by jurisprudential norms and precedent, is trained in jurisprudence, is beholden to reputational and other social constraints, makes their decisions publicly so that they can be subject to review, and so on. A truly systemic understanding of fairness and reliability concerns more than the explicit legal system, extending to include institutions that train and regulate judges. Fair and reliable trials require the presentation of evidence, but evidence is not simply recitation of facts. The sort of presentation of evidence that contributes to the fairness and reliability of a trial is subject to rules of relevance and standards of fairness and reliability itself. The fairness and reliability of the trial is not merely a function of the fact that it makes room for the presentation of evidence, but of the institutions that study and regulate what constitutes admissible evidence, how it is collected, and so on. When we complain of an unfair trial then, it often makes sense to in fact locate the complaint in the broader system, upon which the fairness and reliability of the trial necessarily depend. The unfairness of the lottery is not just in its arbitrariness but in its place in an overall unreliable system that does not prevent such an arbitrary punitive practice.

But there remains a limit to what systemic procedural rights can do. I can explain why Sandra is wronged but again I appealed to systemic features rather than the particular fact that the lottery was arbitrary. Even if there is something wrong in Justland, I must admit that no system is perfect, so there is always the possibility that someone could be subject to an unfair trial 
within a system that was otherwise as realistically good as I want to stipulate, i.e. within a system that did not violate their systemic procedural rights. Call such a case Justland+. Consider Sandra+, who is punished following a trial where a single rogue investigator manufactured evidence in such a way that is not reasonably discoverable by the system. The possibility of such a case cannot be ruled out for human institutions in all their fallibility. If the wrong of an unfair trial is only systemic, then it looks like Sandra+ is not wronged since she, like Sandra, actually committed the crime that she is framed for. The right to a fair trial in the traditional sense is precisely primed to identify particular wrongs like this but the more systemic right finds no fault.

\section{THE ROBUST GOOD OF SECURITY}

To review, appealing to a pre-institutional moral right against unreasonable risk of punishment can ground pre-institutional rights to the establishment and operation of institutions that follow certain procedures. Such rights constrain choices among institutional alternatives and so fulfill the role of procedural rights in one important sense. But systemic procedural rights cannot ground a claim that someone is wronged by a particular instance of punishment imposed without following certain procedures. We have good reasons to want to be able to explain such wrongs. In this section I make the case for a more specific procedural right that can play precisely this role. 
A caveat: my argument in this section is more controversial than the argument for systemic rights. There I appealed to widely accepted premises like a right against unreasonable risk. In this section I employ significantly more controversial conceptual and moral premises, so some who may be convinced by my case for systemic rights may remain unmoved by the case for more specific procedural rights in this section. Importantly, the two arguments are entirely independent of one another, although they present a richer picture of procedural rights when taken together.

When Sandra (or Sandra+) is punished by the lottery, she is harmed beyond simply the costs of punishment or the risk of punishment. Sandra also suffers the denial of a robust good to which she has a right. The idea of a robust good comes from Philip Pettit and it rests on the distinctive notion of robustness, according to which an agent controls for a certain outcome across relevantly close possible worlds. ${ }^{20}$ For our purposes the important

20. PEtTit, supra note 4 . A look at the text reveals the range of theoretical commitments that Pettit draws upon, including in ethics, action theory, and other domains. However, I think that the idea of robustness- of controlling for outcomes in one's deliberations through dispositions of concern-can be extracted from Pettit's broader theory, including his conclusions about what degree of robustness is required for certain goods and about political philosophy. This is why I think it is fair below to present my argument as a particular way of explaining a general constraint of respectful treatment that others discussing punishment have appealed to without using Pettit's framework. Teasing out the nuances of the idea independent of all of Pettit's arguments is a large task that must be put aside for our purposes here. 
point is this: Sandra is wronged by the lottery because she would have been punished even if she had not committed the crime. This is not simply about an increased risk of undeserved harm, as Wellman admits occurs in the case where the punitive lottery is a regular practice. The lottery is not like an accident; it is not something that simply happened. The Justlanders employed the lottery specifically with the intention to inflict hard treatment on someone regardless of their culpability. They would have punished Sandra even if she had not committed the robbery, which is obvious since they punish her even though they do not believe she committed the robbery. It does not matter to them whether she deserves the punishment she receives. Despite the fact that she actually does deserve the punishment she receives, being treated in this manner is itself a harm that Sandra did notindeed, could not—forfeit her right against.

The point of this section is to make good on these claims by further investigating the idea of a robust good and to show that we have a preinstitutional moral right that protects us against the sort of harm that Sandra suffers. I take myself to be explaining something that various theorists have gestured towards when discussing procedural rights. For example, Simmons writes, "we forfeit rights by our misconduct only to the extent that makes possible respectful punishment."21 This notion of respect is also connected to

21. A. John Simmons, Locke and the Right to Punish, 20 PHIL. \& PuB. AfF. 311 (1991), at 341. Original emphasis. Simmons attempts to explain this idea of respect in contractarian terms 
the idea of individualization: punishment must be tailored to the individual, taking account of her particular circumstances. While the general idea is relatively commonplace, its precise grounds are often less well explained and grounding it in robust goods is, as far as I am aware, completely novel. ${ }^{22}$

\section{A. Robust Goods}

To understand how I employ the notion of robust goods in the case of procedural rights, it will help to first step outside the context of punishment. Friendship is one of Pettit's paradigmatic robust goods. For every robust good, there is an associated thin good, which in the case of friendship is care and attention. Friends treat each other with care and attention but simply providing care is not sufficient for friendship. Someone who provides you care only when it is convenient for them and when it advances their interests is not your friend because they give the thin good of care but never the robust good of friendship. As Pettit notes, "the fair-weather friend is no

by appealing to what equal subjection to a system of norms requires, as well as in Kantian terms by appealing to not being used as a mere means.

22. Regarding precise grounds, Duff is a notable exception, offering a detailed argument that connects particular features of punitive systems to the demands of respect for others in a Kantian sense, as autonomous moral agents whom the law calls to account; see DuFF, supra note 3 , at 6 . In distinct contrast, my focus is on how we must treat others when we risk harming them. 
friend at all."23 They may provide you with care on particular occasions and you may believe them to be your friend, but they are only your friend if they not only provide care but control for providing care over a suitable range of counterfactuals or possible worlds, including some where it is costly to them. When they control for giving you care in this way, they give you care robustly and so also give you friendship.

The notion that friendship requires the provision of a robust good is related to the idea that true friendship is necessarily non-instrumental. ${ }^{24}$ When I provide the good of friendship, Pettit argues, I do so out of concern for you in particular, not just for the idea of friendship in general or because of the goods that I might gain from our friendship. I cannot be willing to swap friends in an instant if I think it would be abstractly optimific for me to do so. Instead friendship necessarily involves individualized concern and a disposition to provide friends with care when appropriate. When friends control for caring for one another across a suitable range of relevant possible circumstances, they express the value that they place in their relationship and the respect that they reciprocally have for each other.

A notable advantage of the robustness schema is that it steers us away from conceiving of relations to others solely in terms of expected value. ${ }^{25}$ If

23. PETTiT, supra note 4 , at 35.

24. Dean Cocking and Justin Oakley, Indirect Consequentialism, Friendship, and the Problem of Alienation, 106 Eтнісs 86 (1995).

25. PETTIT, supra note 4, ch. 5. 
you are my friend, it is true that I get more expected care from you than I would otherwise, but that is not what makes us friends. What makes us friends is that I have a special, protected role in your deliberations. It is a decision you make, and keep making through the maintenance of a favorable disposition, to treat me-me specifically-as a friend. I am protected from your ill-will and certain bad outcomes because of my place in your deliberations, not simply because you are a mechanistic source of value for me. To treat friendship as a matter of expected value is to take the objective stance towards friends, to treat friends as mere things, rather than to take the reactive stance that is appropriate when dealing with a person who you recognize can exercise choice and so whom you must trust to use their discretion wisely. Evaluating situations in terms of their expected value works well in some cases, but when applied to our relations with other persons, it treats us all too mechanically. (As I explain below, for our purposes this matters because a risk of harm from something impersonal like a natural disaster is different from a risk of harm from another person's intentional actions.)

Pettit uses the same basic structure-providing thin goods out of a disposition that controls for the provision of those goods across a relevant set of close possible worlds-to analyze not only friendship but love, honesty, respect, and many other goods, ultimately claiming that the general schema is widely applicable. ${ }^{26}$ Following this lead, Seth Lazar recently

26. Id. at 108 . 
applied the idea of robust goods to issues of harm and risk. ${ }^{27}$ Lazar's discussion is illuminating given our concern with these same issues, although modified to fit our context of punishment.

Lazar argues that, all else equal, killing an innocent is worse when that killing is riskier precisely because riskier killings fail to give others the robust good of security that they deserve. The good of security is

robust avoidance of pro tanto wrongful harm. To enjoy security, one must not only avoid wrongful harm in the actual world, but also do so across relevant counterfactual scenarios: those in which the victim does not get lucky. We are insecure to the extent that others make our avoidance of wrongful harm depend on luck. ${ }^{28}$

Just like friendship, security as a robust good has important instrumental benefits, such as peace of mind, but is also non-instrumentally valuable. Security, Lazar argues, partly constitutes autonomy because being insecure gives you less control over your life. ${ }^{29}$ Security also partly constitutes what it means to be a member in good standing of a community, where others

27. Seth Lazar, Risky Killing, J. MoRAL PHIL. (forthcoming); Seth Lazar, Risky Killing and the Ethics of War, 126 Ethics 91 (2015): 91-117. Cf. Pettit, supra note 4, at 175-76.

28. Lazar, Risky, id. at 8.

29. Cf. Oberdiek, supra note 10 , at $373 \mathrm{ff}$. 
express their concern for you through a disposition to protect you against wrongful harms. ${ }^{30}$

A modified version of one of Lazar's examples can help us better understand the robust good of security. Consider Allie, a worker who is tasked with demolishing a building. Unbeknownst to Allie, Bruce is in the building. Allie knows that there could be people in the building-such a possibility is intrinsic to the task of demolishing large structures. In the first case, she thoroughly checks the building because she is concerned with people's lives: she does not want to kill anyone and it is relatively easy for her to take the time and effort to go through the building before she destroys it. She finds Bruce and removes him. In this case she gives Bruce the robust good of security and expresses her concern for others in her community, including Bruce. ${ }^{31}$ In the second case, she decides not to check and demolishes the building, killing Bruce. In this case, not only did she violate his right to life, she failed to give him security: she was indifferent to the very live possibility that someone might be in the building she was going to demolish. Finally, in the third case, she decides not to check but Bruce is able

30. Lazar, Risky, supra note 24, at 8-9.

31. Note that the only role of this case is to illustrate robust goods and how to consider them. Their particular role in justifying procedural rights is articulated below and the contrast with other ways of accounting for similar concerns, like focusing solely on levels of risk, is emphasized at that point. These other methodologies may well account for the Allie case just as well as robust goods do; the point is the distinct roles they play with respect to punishment. Thanks to an anonymous reviewer for pushing me to clarify this point. 
to escape with his life. In this case she did not violate his right to life but she did fail to give him security precisely because she still acted on her indifference to the possibility that he was in the building and that he might be wrongfully killed. ${ }^{32}$ Bruce is alive but insecure: the fact that he lived was a result of luck, not of Allie controlling for avoiding wrongfully harming him.

The proposed robust good of security is intuitively plausible. Critics may want to account for security-or even robust goods in general—strictly in terms of expected value, or blameworthiness rather than permissibility, or

32. There is a fourth possibility: Allie checks thoroughly but Bruce is undiscoverable and he dies when she demolishes the building. My inclination is to say of this case that Allie gave Bruce the good of security—she surely did not violate any right he has to securitybecause she did her due diligence but that she still violates his right to life (since he had done nothing to forfeit or waive it). Bruce was as secure as Allie could make him but security is not everything. The way Pettit defines robust goods seems to make this impossible, though, because one can only give someone a robust good when one also gives the thin good and Allie did not secure the thin good of avoiding wrongfully harming Bruce. This is one place where our theory of robust goods can come apart from Pettit's but it is also tangential to our discussion of procedural rights. One thing we can agree on is that Allie expressed the concern that security requires and that she treated him as person with equal status in her community, as far as she was able. (Analogously, there may be cases where someone acts as a friend should, and so remains your friend, even when she cannot give you the thin good of care for reasons outsider her control, like if she suffers a debilitating accident.) 
with a variety of other strategies. ${ }^{33}$ I will not pretend to have given the robust good of security a full defense. As I noted above, my argument here depends on considerably more controversial premises, in particular the existence of a robust good of security. From here forward I will take such a good to exist in order to explore the possibility that it can ground pre-institutional moral procedural rights.

\section{B. To Procedural Rights}

Even if there is a robust good of security, I still need to show three things for the purposes of grounding procedural rights. First, that we all have a preinstitutional moral right to the provision of security from other individuals. Second, that such a right requires that we follow specific procedures in our treatment of others, especially in the case of meting out punishment. Third, that such a right is not forfeit by culpable offenses.

If I can show all three elements, then we can say that everyone has a right not to be punished by other individuals absent fair procedures, even in the state of nature and even against the background of a sufficiently reliable punitive system, because doing so would fail to provide them with the robust

33. Lazar addresses some of these concerns in the case of security and, of course, Pettit considers many in the general case of robust goods. It is worth noting that Wellman pursues similar sorts of debunking strategies against other proposed grounds for procedural rights, so he may well be amenable to pressing them here as well. 
good of security (or: doing so would make them wrongfully insecure.) Punishing Sandra using a punitive lottery thus wrongs her because it violates her procedural rights that are derived from her right to security. Similarly, punishing someone in the state of nature without first going through a trial and other sufficiently fair and reliable procedures wrongs them. If this is true, then we will have found a ground for pre-institutional moral procedural rights of the sort that can play the role of identifying the particular wrong of punishing absent appropriate procedures in particular cases, across the variety of contexts in which those judgments seem apt. The remainder of the article takes up these three tasks.

First, even if security is a robust good, and even if we all have interests in such a good, why think that this amounts to a right to security? ${ }^{34}$ We do not have a right to all good things or to all good sorts of treatment; romantic love is a robust good on Pettit's account but nobody has a right to be romantically loved that correlates to another person's duty to love them. ${ }^{35}$ Further, as Alexander notes, it is not plausible that there is a duty to follow strict procedures whenever we risk setting the interests of others back

34. Lazar mostly refrains from discussing a right to security because his concern is with its exacerbating or aggravating role but he says that a right to security is plausible. See Lazar, Risky, supra note 24 , at 7 , note 20 , and 16 .

35. Wellman, supra note 1, at 298 raises a similar complaint against a publicity constraint: it may be good for justice to be done publicly but that is distinct from having a right to public justice. 
because anything we do entails such a risk. ${ }^{36}$ It would unreasonably explode our duties.

To me, it is plausible that while we have an interest in security broadly speaking, we only have a right to security when our most essential interests are at stake. ${ }^{37}$ If I demonstrate a lack of concern such that I risk lightly scratching your forearm, I may have made you less secure and I may have acted blameworthily but I do not seem to have not violated any of your rights. ${ }^{38}$ But it is harder to deny a right to security when we are considering avoiding violations of essential interests, like simply remaining alive. This is

36. Alexander, supra note 3, at 33.

37. This distinction could collapse if pro tanto wrongs of the sort referred to in Lazar's definition of security are restricted to violations of essential interests. But this seems too strong: because of my property rights it is pro tanto wrongful to harm my property, for example by scratching my car, but having an unscratched car seems in no way essential to my well-being. Some wrongs are minor.

38. Restricting the right to security to cases of essential interests answers an argument from Wellman, supra note 1, at 296-97. He gives the example of Elizabeth and Philippa: Philippa takes twenty dollars from Elizabeth but later Elizabeth, not knowing Philippa had taken her money and fully intending to steal from Philippa, takes her own twenty dollars right back. Wellman contends that Elizabeth has done nothing wrong (although she is blameworthy). If a right to security covered wrongful harms of any kind, it might run afoul of this case (assuming you agree with Wellman's assessment). But while Elizabeth might be undermining Philippa's interest in security, since it only involves a small amount of money Philippa's right to security does not cover such a case and so Elizabeth has not violated Philippa's rights in this case. 
why the Allie case is compelling. If you are undertaking a task that is very destructive and you know that someone could easily be killed by your actions, to proceed without taking precautions demonstrates a critical, wrongful lack of concern for the lives of others.

When Bruce barely escapes with his life, he has a complaint not just because there was some chance that he would die but because Allie did not even do the bare minimum to ensure that her risky action would not kill anyone. As Lazar emphasizes, it is not just that there was some objective risk of Bruce dying but that Allie acts without knowing whether she is risking killing anyone and without even attempting the clear steps that she could take to find out. Another way of framing this is that the good of demolishing the building without securing the site is very much outweighed by the bad of a wrongful and unnecessary death, so when proceeding to demolish the building without due diligence, the reckless version of Allie is expressing how little she actually values the lives of others and how much she undercounts their worth when she acts. She does not give others' lives the protected place in her practical deliberations that she should by controlling for avoiding wrongfully killing or injuring them. This is also why such a right is clearly held against individuals: it is about how we are each obligated to treat others when we undertake actions that we know risk harming others' essential interests.

Such a right to security also seems to be a pre-institutional moral right, so obligates us to act in certain ways even absent relevant 
institutions. ${ }^{39}$ If I am going to undertake a risky task, like burning down a field that separates my house from my neighbors' house, it is clear that I wrong my neighbors if I do not take sufficient care for their lives. I need to warn them; I need to set up firebreaks; in general I need to make sure that my act does not threaten to burn down their house and kill them. Otherwise they clearly can complain that I did not express adequate concern even if I get lucky and they are not harmed. It is true that ultimately the details of such concern need to be specified by institutions, so out of the state of nature, but disagreement over borderline cases should not prevent us from

39. Note also that the duty correlated to this right holds even when someone in the state of nature has done their fair share to establish institutions that would better protect and respect this right. Consider an analogy to emergency aid services, an issue of importance for Wellman's Samaritan justification for the state. One implication of the pre-institutional rights that people have is that they be aided when they are in danger and aid is of little cost to bystanders. The only way to secure these rights generally in our actual conditions, where natural disasters and accidents and so forth are a regular, if unpredictable, feature of the world, is to set up institutions like police and firefighters and paramedics. Imagine someone who has done their fair share in the state of nature to set up such institutions but, because other people are not contributing, such institutions do not exist. This does not mean that if this person comes across a situation of easy rescue that she does not have a duty to aid the person in harm's way. The institutional duty and the individual duty may rest in the same concern for the person as an individual who matters, but fulfilling one does not entail fulfilling the other. Similarly, then, even the person who has done her fair share to set up fair punitive institutions but remains in a state of nature still has the duty not to make others insecure in their essential interests. 
saying that taking risks with others' lives without sufficient precautions can sometimes clearly wrong them by denying them the security that they deserve.

A complete defense of the right to security would need to go more deeply into rights theory; an important interest in security plausibly grounds the right to security on an interest theory of rights but it is a more open question whether a will theory of rights would also endorse the right to security (although the non-instrumental value of security in partially constituting autonomy suggests that it could). I cannot undertake such a project here but it is plausible that we have such a right. If we are owed concern from others, it makes sense to say we have a right that they control for avoiding wrongful harms when they risk setting back our essential interests. Thus it is plausible that we all have a pre-institutional moral right to the provision of the robust good of security held against other individuals, which correlates to a duty to provide security on their part-in short, a right to security.

Turning to our second main task: even if we have a right to security, why think that this right requires certain procedures to be followed, such that procedural rights can be derived from the right to security? The Allie example is helpful here as well. Given that demolishing the building involves a lot of destruction and would almost surely kill anyone inside, Allie has a duty to check the building for occupants before demolishing it based in people's right to security. Surely not any procedure will suffice in order to 
fulfill her duty to provide security: simply calling a quiet warning from outside is not sufficient. She must check the whole building. If she did not follow the procedure of inspecting every room in the building before destroying it, she wrongs anyone in the building in virtue of her lack of concern for their well-being. Given the nature of the task that she is undertaking and the risk that she poses to others' lives, particular sufficiently reliable procedures are required and others have a right against her using insufficiently reliable procedures like only calling from outside or only checking the entrance. Like rights against double jeopardy or the use of punitive lotteries, this is a negative procedural right that protects us against procedures of certain sorts.

To my mind this example suffices to show that in cases where people's sufficiently important interests are at stake such that they have a right to security, that right can only be respected by following certain procedures. In other cases where security matters less, so there is only an interest and no right as in cases where severe physical harm is not realistically possible, it may be the case that you can provide someone with the robust good of security absent following procedures. But when the interest is important enough to ground a right, procedures are necessary.

That said, the case for procedural rights derived from the right to security is even clearer in the case of punishment. In Allie's case, she does not know whether anyone is in the building; it might be that nobody is harmed by her act. But punishment necessarily involves the intentional infliction of 
harm. There is no chance that nobody will be harmed by punishment because harm is intrinsic to punishment. When intentionally inflicting harm, the only way to also provide security is to follow rigorous procedures.

Providing security while harming may seem paradoxical on its face. The first thing to note is that we defined security as avoidance of pro tanto wrongful harm, not just harm per se. Consider the sort of harm involved in a martial arts bout. The harm here is not wrongful because it is consensual. But participants can still undermine the other's security if they go beyond the regulations that restrain the harm, for example if they modify their equipment or use banned techniques. The harm participants inflict on each other can remain within the bounds of concern and security; indeed, to be indifferent to the regulations of the sport or to purposefully flout them precisely expresses a wrongful lack of care given the gravity of the practice.

Notice that intentionally inflicting harm is prima facie wrongful. When we undertake to intentionally inflict harm, then, to avoid pro tanto wrongful harm we have to confirm that the harm is not wrongful, for example by confirming waiver, necessity, or forfeiture. ${ }^{40}$ The only way to sufficiently

40. The distinction between pro tanto and prima facie wrongs matters a great deal for our purposes here. A pro tanto wrong is genuinely wrongful but it may be outweighed all things considered, so it may be justified to inflict the wrong. A prima facie wrong is only wrong in usual circumstances; in some circumstances it may not be wrong at all. A prima facie wrong can become pro tanto wrong when we consider it in particular circumstances. The point, then, is that since intentionally harming is usually wrong, absent special circumstances, to show appropriate concern for avoiding actually wronging someone 
reliably confirm the permissibility of intentionally inflicting harm and so to sufficiently reliably control for avoiding pro tanto wrongful harm is to follow procedures-probably redundant procedures-before inflicting the harm. ${ }^{41}$

Since punishment necessarily involves intentionally harming others, it must follow procedures in order to control for avoiding wrongful harms. The particular procedures required depend on the nature of the practice. The intentional harm of punishment is not wrongful only when a person has forfeited her rights against punishment by culpably committing an offense. The procedures that must be followed to protect against pro tanto wrongful harm in the case of punishment, then, must be the procedures that sufficiently test that punishment is deserved because the offender has forfeited her rights against punishment by committing the relevant act and because she was culpable for doing so. Such procedures thus must take the when we intentionally harm them, we have to be very sure that the special circumstances are met.

41. This is perhaps more complicated in the case of defensive harm, where time is often a factor and so following procedures may be self-defeating. That is not a concern in our context of punishment. But notice that even in the context of defensive harm, the time crunch is why we want the people who are most likely to have to deal defensive harm follow strict procedures in their training. We try to inculcate the appropriate procedures into the level of reflex precisely so the procedures can control the imposition of harm even under severe time constraints. This is why police practice shooting courses where some targets are innocents: it builds the procedure of checking for innocence (if at a shallow level of appearance) into the moment where wrongful harm is most likely and most devastating. 
form of judicial procedures we are familiar with: the presentation of evidence on both sides to disinterested third parties, standards of evidence to be met, the possibility of appeal, and so on. Because the intentional infliction of harm is such a grave matter and because we have a duty to provide security for others, when we punish we have to follow especially rigorous and redundant procedures to ensure that we are avoiding pro tanto wrongful harm. Otherwise we fail to do our duty of providing security to others and thereby wrong them.

In the context of Wellman's skeptical challenge, it is also especially important to note the modal character of the right to security: robust goods have to control for outcomes across a relevant range of close possible worlds. In Lazar's terms, we have to make sure not only that we do not wrongfully harm but that others do not depend on luck or chance to avoid wrongful harms. (Note that the Justlanders get exceedingly lucky that they do not wrongfully harm Sandra. It was a one in ten million-the population of Justland-chance that the lottery picked the actual robber and when you take into account the possibility that Sandra committed the robbery but was not culpable, the odds of having not wrongfully harmed her are even lower.) To provide the robust good of security to others, it is not sufficient that we do not wrongfully harm them. We have to control for not wrongfully harm them by giving them appropriate concern in our deliberations about how we act. We owe them this concern out of the basic respect that follows from recognizing that they matter, that intentionally inflicting harm is usually 
wrong, that we are fallible, and further that punishment is a practice that is historically rife with abuse. Punishing without following rigorous procedures wrongs others because it does not give them the security they deserve.

So we have a pre-institutional moral right to security that requires that we follow certain procedures, especially when we intentionally inflict harm as in the case of punishment. But all this would be irrelevant to Wellman's skepticism if we forfeit our right to security when we forfeit our right against punishment. For example, it is clear that if rights forfeiture were absolute, i.e. culpably committing an offense forfeits all of one's rights, then Sandra is not wronged regardless of any consideration of security. But such an absolutist view of rights forfeiture is implausible; one of the main tasks of a rights forfeiture theorist is to make clear which rights are forfeit and to what extent, thereby giving forfeiture plausible limits. Just because someone committed a robbery does not we can punish them by killing them or torturing them. Such is a standard liberal commitment to the existence of limits on treatment demanded by the inherent respect due each person. So the question is: even if a culpable offender forfeits her rights against an appropriate punishment, and even if she forfeits her rights against the risk of that punishment, does she forfeit her right to the provision of the robust good of security? I claim that she does not.

The important point is that security is not reducible to minimizing risks or maximizing expected value. If it were then Sandra would forfeit her right to security, just as she forfeits her right to a risk of punishment that she 
deserves. But security is more than risks; again, it has non-instrumental value and is instantiated by a certain kind of treatment, not simply an impersonal estimation of the likelihood of harm. It is a demand made by the status of others as persons who matter and whose lives we have to express concern for by giving them a protected place in our deliberations when considering how to treat them.

Its foundation is the same as the right against torture or cruelty. The right to security is an ineliminable part, I think, of a broadly liberal approach to punishment. We do not condemn persons in their entirety or in perpetuity for committing crimes. We think that even the guilty who deserve punishment have moral rights and can appropriately make certain demands of us. Chief among these is the concern to avoid wrongfully harming them when we inflict punishment, not simply to avoid punishing them when they are innocent but also to avoid over-punishing them.

If this is right, then Sandra is wronged by the punitive lottery even though she forfeited her right against punishment because the Justlanders' violate her right to the robust good of security when they do not follow procedures that control for avoiding inflicting pro tanto wrongful harms. As I wrote above, Sandra is wronged by the lottery because she would have been punished even if she had not committed the crime. The Justlanders do not show her sufficient concern.

The idea that punishment has to follow certain procedures in order for people to be secure is intuitively very plausible. Recall Lazar's idea that 
security is non-instrumentally valuable because of the role it plays in autonomy and in our standing in community. Being punished without concern for avoiding wrongful harms undermines our ability to choose for ourselves and indicates a lesser status than we deserve. The wrongs are even clearer in aggregate: in societies where punishment is not constrained by extremely demanding procedures, the possibility of arbitrary and undeserved punishment undermines people's security in precisely these ways. They become less able to control their lives, which is bad in itself and also has extremely detrimental consequences, and they are less able to assert standing in the community, becoming obsequious or reserved. In such societies whether your life will continue to be decent depends largely on luck and also creates many more opportunities for abuse and oppression on the part of authorities by granting them wider discretion because they are less constrained by formal procedures.

In sum, the right to security grounds procedural rights that explain the wrong done to a person by being punished without the punishing agent having controlled for avoiding wronging her, the second major role we identified for procedural rights in section one. In combination with systemic procedural rights, then, we have different sorts of procedural rights that play both important roles that we identified. But it may be the case that procedural rights grounded in security can also play the role of constraining choices between institutional alternatives. For example, if what counts as sufficient control for avoiding harming requires not just following certain 
procedures but following procedures that are embedded within, and gain reliability from, a sufficiently reliable system, then the right to security will ground systemic procedural rights as well. In that case we could have a complete theory of procedural rights grounded only in the right to security. That said, my purpose here is to address the skeptical challenge to procedural rights in general, so I will not pursue the idea of extending the (admittedly controversial) right to security.

To briefly conclude, Wellman's arguments against some procedural rights are important and should affect how we think of the justification of our judicial institutions. However, his very general conclusion that there are no general, moral, judicial, procedural rights is false. First, our general right against unreasonable risk, including unreasonable risk of punishment, grounds systemic procedural rights that demand our practices of punishment be institutionalized and that those institutions follow sufficiently reliable procedures. Some procedures will be ineliminable from such a system, including the general procedure of a trial, but other procedures that we have sometimes taken to be important elements of rule of law, like a right against double jeopardy, may not be. Second, our right to the provision of the robust good of security grounds procedural rights because we have the right that others take care to avoid inflicting pro tanto wrongful harms on us. Punishment is prima facie wrongful since it is the intentional infliction of grave harm, so the only way to punish people without making them insecure is to use exceptionally reliable procedures to test the claim that punishment 
is permissible in a particular case, taking account of the victim of harm in all their individuality and demonstrating appropriate concern for them as a person even if they are a culpable offender. ${ }^{42}$

42. Compare RONALD DWORKIN, TAKING RightS SERIOUSLY 13 (1978). 